\title{
Dissimilarity in plant species diversity between salt marsh and neighboring environments decreases as environmental harshness increases
}

\author{
Alejandro D. Canepuccia ${ }^{1,2, *}$, Claudio F. Pérez ${ }^{2,3}$, Juan L. Farina ${ }^{4}$, \\ Daniela Alemany ${ }^{1,2}$, Oscar O. Iribarne ${ }^{1,2}$ \\ ${ }^{1}$ Laboratorio de Ecología, Instituto de Investigaciones Marinas y Costeras (IIMyC), \\ Universidad Nacional de Mar Del Plata (UNMDP), CC 573 Correo Central, B7600WAG, Mar del Plata, Argentina \\ ${ }^{2}$ Consejo Nacional de Investigaciones Científicas y Técnicas (CONICET), Av. Rivadavia 1917, C1033AAJ, \\ Buenos Aires, Argentina \\ ${ }^{3}$ Departamento de Ciencias de la Atmosfera y los Océanos (FCEyN), Universidad Nacional de Buenos Aires, \\ Int. Güiraldes 2160, Pab. 2, C1428EGA, Buenos Aires, Argentina \\ ${ }^{4}$ Museo de Ciencias Naturales Lorenzo Scaglia, Área Entomología, Mar del Plata, Av. Libertad 3099, CP 7600, \\ Buenos Aires, Argentina
}

\begin{abstract}
How species similarity changes between habitats along environmental gradients is still a central challenge in ecological studies. We assessed whether marsh plant characteristics are associated with geographic changes in environmental conditions and whether there are environmental factors associated with marsh-inland dissimilarity in species composition. Field samples of vegetation were collected at 6 sites along the SW Atlantic to determine plant characteristics (cover, tallness, richness and $\alpha$-diversity), and marsh-inland dissimilarity ( $\beta$-diversity) in species composition was calculated. PERMANOVA analysis showed that plant assemblage changes among sites. Forward stepwise multiple regression analysis showed that in lower marsh, plant cover increased in association with tidal range and decreased in association with salinity. In the high marsh, plant cover decreased in association with tidal range, salinity and with minimum temperatures. Plant richness increased in association with tidal range and with marsh area, while $\alpha$-diversity decreased in association with precipitation and increased with salinity. Beta-diversity, estimated by SIMPER analysis, increased in association with precipitation and decreased with salinity and daily thermal amplitude. We present evidence that there is an increase in $\alpha$-diversity but a decrease in $\beta$-diversity with environmental severity among co-specific marshes distributed along the SW Atlantic coast. Thus, communities developing in more benign conditions, regardless of their low local diversity, may increase biodiversity at a landscape scale by decreasing their similarities.
\end{abstract}

KEY WORDS: $\alpha$ - and $\beta$-diversity - Climate variables - Latitudinal gradient - Physical factors . Spartina $\cdot$ Tidal salt-marshes

\section{INTRODUCTION}

One of the most recognized ecological patterns is that species richness varies with latitude (e.g. Whittaker et al. 2001, Hillebrand 2004). However, latitude is just a proxy of environmental drivers that lead to these biodiversity changes (e.g. Willig et al. 2003,
Andrew et al. 2012). Indeed, these changes are likely to be associated with the compatibility of the physiological, morphological and/or life-history traits of species with the physical filters along environmental gradients (Keddy 1992, Andersen et al. 2012). Several coexisting factors associated with differences in water-energy amounts (Hawkins et al. 2003, Whit- 
taker et al. 2007, Eiserhardt et al. 2011) and with changes in environmental heterogeneity (e.g. daily thermal amplitude; Speziale et al. 2010) have been proposed as the main environmental forces driving changes in plant richness and composition of terrestrial communities throughout the world.

Concomitantly with these changes in species richness, dissimilarity in species composition between neighboring communities (e.g. $\beta$-diversity; Whittaker 1972, Harrison et al. 2006) can also change, varying the regional diversity along gradients of environmental harshness (Tscharntke et al. 2012). For example, in more constraining environments, organisms may show a more generalist physiology and ecology (Stevens 1989), allowing them a broader distribution across landscapes (Stevens 1989, Clarke \& Gaston 2006). This potential for widespread distribution could increase the similarity between communities. In contrast, in more benign environments (e.g. with less seasonality and higher productivity), as a result of an increase in habitat specialization, there could be an increase in between-communities species turnover (Stevens 1989, Stevens \& Willig 2002, Clarke \& Gaston 2006) which could increase the dissimilarity between neighboring communities and the diversity at a regional scale. However, there have been contrasting results (see Koleff et al. 2003, Tscharntke et al. 2012 and cites therein), showing that the association of species similarity between habitats and environmental severity is far from being elucidated. Thus, an understanding of the differentiation among habitats in species' $\alpha$-diversity (as in their $\beta$-diversity) along geographic gradients still remains a central challenge in ecological studies (Andrew et al. 2012, Tscharntke et al. 2012).

Tidal marshes develop between terrestrial and aquatic ecosystems, along low energy coastlines worldwide (Wiegert et al. 1981, Mitsch \& Gosselink 1993). As an interface, tidal marshes share characteristics with their neighboring habitats but have their own unique features (Mitsch \& Gosselink 1993), such as having strong physical gradients (Bertness 1991, Bertness et al. 1992) and being dominated by a few very widespread species which develop under a wide range of environmental harshness conditions across large geographic regions (Mitsch \& Gosselink 1993, Pennings \& Bertness 2001, Isacch et al. 2006). Recently, large-scale studies have found that herbivore-marsh plant interactions are more intense at lower latitudes along the east coast of North America (Salgado \& Pennings 2005, Pennings et al. 2009), in Europe (Pennings et al. 2007) and in South America (Canepuccia et al. 2010a, 2011) and that variation in grazing intensity may be related to changes in herbivore densities among locations (Alberti et al. 2007, Pennings et al. 2009). However, information is scarce about the environmental variables that shape the geographical zoning and distribution of vegetation in tidal marshes. Given that the harshness of environmental conditions in marshes often varies with latitude (Pennings \& Bertness 1999, 2001, Pennings et al. 2007, Isacch et al. 2006, Canepuccia et al. 2011), salt marshes constitute an interesting habitat to analyze in order to determine whether environmental severity is related to biodiversity and the species shared with neighboring habitats, thus minimizing the artifacts resulting from comparing different habitats or distant taxa. From the La Plata river outlet $\left(35^{\circ} 13^{\prime} \mathrm{S}\right)$ to northern Patagonia $\left(40^{\circ} 50^{\prime} \mathrm{S}\right.$; both in Argentina), there are some of the most extensive Spartina spp. marshes of the SW Atlantic coast (Isacch et al. 2006). These Spartina marshes are distributed along environmental gradients of tides, water salinity, precipitation and temperature that vary predictably with latitude (Cabrera \& Willink 1973, Isacch et al. 2006). Changes in these environmental factors are known to affect the abundance and richness of plant species (e.g. water availability: Hawkins et al. 2003, O'Brien 2006, Eiserhardt et al. 2011; thermal heterogeneity: Pennings \& Bertness 1999, Speziale et al. 2010; salinity: Pennings \& Bertness 1999, Hu \& Schmidhalter 2005, Isacch et al. 2006). On the Argentinean coast, Spartina marshes are limited - on the inland sideby 3 different biogeographic provinces (Cabrera \& Willink 1973, Isacch et al. 2006). The northern marshes are limited by the 'Pampas grassland biogeographic province', which is characterized by a warm-temperate climate with abundant precipitation and dominated by a grass steppe. The marshes located in the central part of this distribution are surrounded by the 'Espinal biogeographic province', characterized by thorn trees and halophytic grasses, which grow in warmer and drier conditions. The marshes located in the southern part of this distribution are surrounded by the 'Monte biogeographic province', which is characterized by a patchy pattern of alternating shrubs and bare soil areas and constitutes the most arid area of Argentina (Cabrera \& Willink 1973, Cabrera 1976; see the 'Study site' section and Fig. 1). Thus, these relatively narrow and homogeneous Spartina marshes develop between 1 marine biogeographic province (Argentine province; Boschi 2000, Balech \& Ehrlich 2008; Fig. 1) and 3 land biogeographic provinces.

Given this background, we used a comparative approach to analyze how vegetation assemblages of 
tidal marsh and its neighboring inland habitat, as well as their shared species, change according to environmental geographic gradients. In environments with greater environmental stress, species may show a more generalist physiology and ecology (Stevens 1989), which may allow them to inhabit a greater distribution range. Thus, the increase in environmental stress could decrease the dissimilarity between neighboring communities. We hypothesized that the species richness of marsh plants and the dissimilarity of this community with the adjacent inland environment decreases with environmental harshness according to geography. Our work aims to describe the general biogeography of marsh and inland plant assemblages along the SW Atlantic coastline, assessing whether: (1) plant assemblage characteristics are associated with geographic changes in environmental conditions and (2) whether certain environmental factors are associated with the species dissimilarity between marshes and inland assemblages along these physical environmental gradients.

\section{MATERIALS AND METHODS}

\section{Study sites}

The study was carried out in 6 marshes, located along the SW Atlantic coast from $35^{\circ} 13^{\prime}$ to $40^{\circ} 50^{\prime} \mathrm{S}$ (Argentina), including some of the most important SW Atlantic Spartina marshes (see Isacch et al. 2006). These Spartina marshes are characterized by 2 main habitats defined by characteristic intertidal heights and the dominance of different plants. The lower marsh develops at the maritime front and is dominated by monoculture stands of the smooth cordgrass Spartina alterniflora. The other one develops at the upper intertidal height and is dominated by the dense-flowered cordgrass $S$. densiflora and the perennial glasswort Sarcocornia perennis (Isacch et al. 2006). The specific sampling sites were: the outlet of La Plata River (SC: San Clemente, $36^{\circ} 22^{\prime} \mathrm{S}$ ), the Mar Chiquita coastal lagoon (MCH: $37^{\circ} 45^{\prime} \mathrm{S}$ ), Bahía Blanca (BB: $\left.38^{\circ} 41^{\prime} \mathrm{S}\right)$, Bahía Anegada (BA: $39^{\circ} 48^{\prime} \mathrm{S}$ ), the outlet of Río Negro (RN: $41^{\circ} 00^{\prime} \mathrm{S}$ ) and Bahía San Antonio (BSA: $40^{\circ} 42^{\prime} \mathrm{S}$; Fig. 1). The northern marshes are exposed to microtides ( $\mathrm{SC}=0.75 \mathrm{~m}$, $\mathrm{MCH}=0.75 \mathrm{~m}$; Isacch et al. 2006), with important freshwater input, and are characterized by brackish water conditions. The southern sites developed in large embayments, in dry coastal areas and with larger tidal amplitudes $(\mathrm{BB}=2.44 \mathrm{~m}, \mathrm{BA}=1.64 \mathrm{~m}$, $\mathrm{BSA}=6.44 \mathrm{~m}$; Isacch et al. 2006). The RN site also developed in a dry coastal area with large tidal amplitudes $(2.94 \mathrm{~m})$, but the freshwater input of the Río Negro leads to brackish water conditions (Isacch et al.

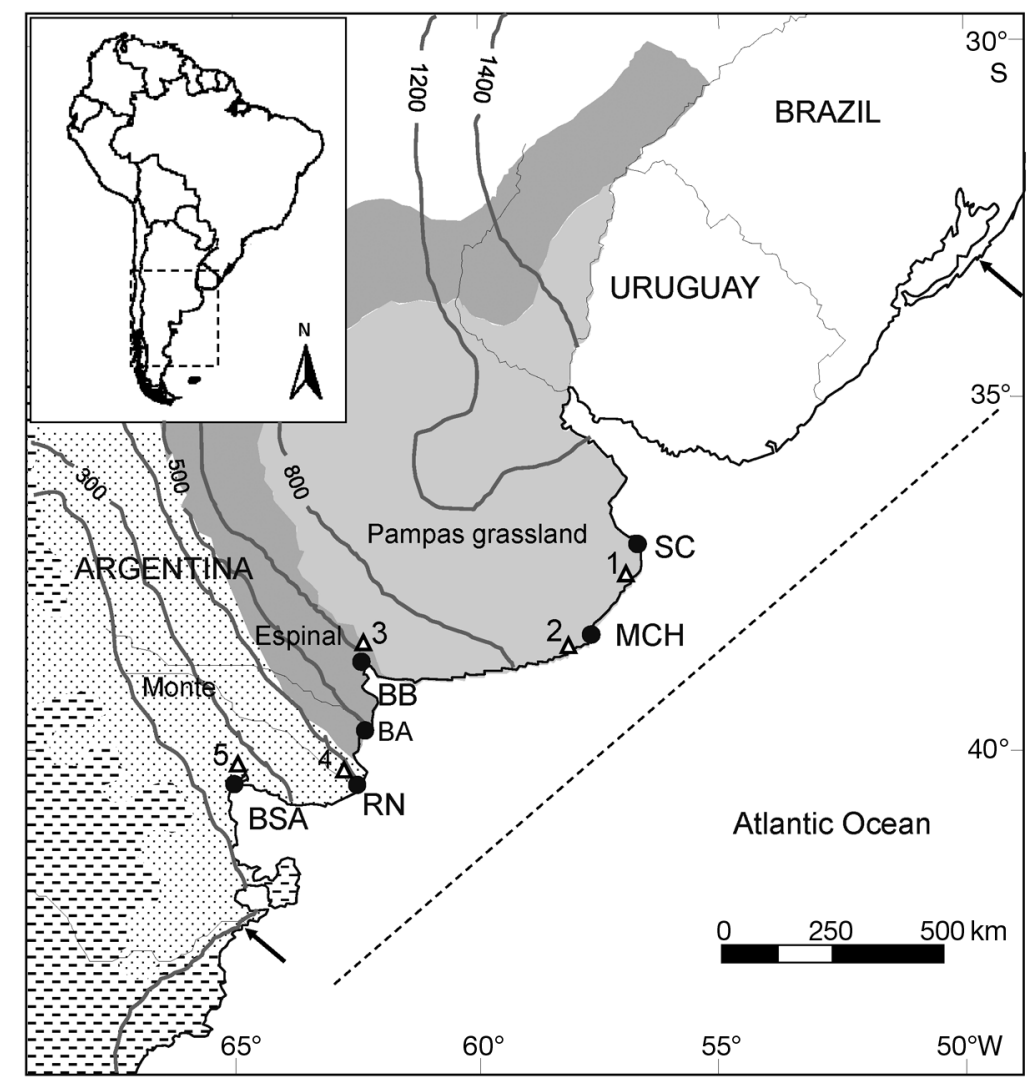

Fig. 1. Marshes sampled along the SW Atlantic coast. SC: San Clemente

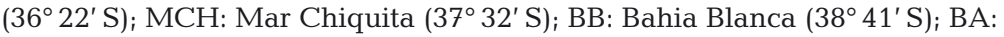
Bahía Anegada $\left(39^{\circ} 48^{\prime} \mathrm{S}\right)$; RN: the outlet of Río Negro $\left(41^{\circ} 00^{\prime} \mathrm{S}\right) ; \mathrm{BSA}$ : Bahía San Antonio ( $40^{\circ} 42^{\prime} \mathrm{S}$ ). SC and $\mathrm{MCH}$ are located in the bigeographical Pampas grassland province (light gray), BB and BA located in the Espinal province (dark grey area), and RN and BSA located in the Monte province (dotted area). Dashed area indicates the Patagonia province. The coast between the arrows shows the area of development of tidal marshes dominated by Spartina spp. grasses. The dashed line indicates the geographic range of the Temperate Argentine Biogeographic Marine province. Triangles indicate meteorological stations. 1: Stn $876580,36^{\circ} 33^{\prime} \mathrm{S}$, $56^{\circ} 42^{\prime} \mathrm{W}, 2 \mathrm{~m}$ above sea level (MASL); 2: Stn 87692, 38 $0^{\circ} \mathrm{S}, 57^{\circ} 33^{\prime} \mathrm{W}, 17$

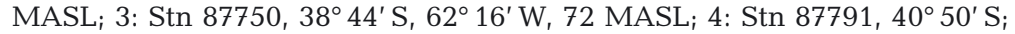
$63^{\circ} 0^{\prime} \mathrm{W}, 12$ MASL; 5 : Stn $87784,40^{\circ} 45^{\prime} \mathrm{S}, 64^{\circ} 56^{\prime} \mathrm{W}, 8 \mathrm{MASL}$. The isohyets for the study sites are gray lines with the rainfall values in millimeters obtained by averaging the period 1961 to 1990 (Argentinean National Weather Service, Servicio Meteo-rológico Nacional Argentino) 
2006). These tidal marshes are surrounded by diverse inland matrices that represent different biogeographic provinces (see Cabrera \& Willink 1973, Isacch et al. 2006). The northern marshes (SC and $\mathrm{MCH})$ are surrounded by the Pampas grassland biogeographic province, which is characterized by an herbaceous layer dominated by grasses of the genera Stipa, Piptochaetium, Rothriochloa and Panicum (Cabrera \& Willink 1973). With a warm temperate climate, this area has an annual precipitation that oscillates between 600 to $1000 \mathrm{~mm} \mathrm{yr}^{-1}$ and a significant input of freshwater from the La Plata River (Isacch et al. 2006). The middle marshes (BB and $\mathrm{BA}$ ) are surrounded by the Espinal province, which is characterized by xeric thorn trees and bushes, such as mesquite Prosopis caldenia and black matorro Cyclolepis genistoides, and scrubs, such as jume Suaeda divaricata, blak jume Allenrolfea patagónica and Heterostachys olivascens. The herbaceous layer is dominated by halophilic grasses, such as desert panicgrass Panicum urvilleanum and dropseed grasses Sporobolus rigens (Cabrera \& Willink 1973). With a temperate and dry climate, this area has an annual precipitation ranging between 400 to $600 \mathrm{~mm} \mathrm{yr}^{-1}$ (Isacch et al. 2006). The southern marshes (RN and BSA) are surrounded by the Monte province, which is characterized by large bare soil areas, dominated by xeric bushes, such as the creosote bushes Larrea divaricata and L. cuneifolia and the salt shrubs Plectrocarpa rougessi (Cabrera \& Willink 1973). With colder and drier climate, this area has an annual mean precipitation of around $200 \mathrm{~mm} \mathrm{yr}^{-1}$ (Isacch et al. 2006).

\section{Diversity of marsh-inland species composition and environmental conditions}

We sampled the herbaceous layer $(<0.5 \mathrm{~m}$ height) and the shrub layer ( $>0.5 \mathrm{~m}$ height) in December 2010 (spring in the southern hemisphere) at 2 marsh elevations, defined as the upper and lower halves of the whole elevation gradient, and in their neighboring inland environments. The herbaceous vegetation was sampled using a line intercept method (Canfield 1941) with 5 replicated $10 \mathrm{~m}$ transects placed $50 \mathrm{~m}$ apart in the inland and low and high marsh areas of each study site (see Fig. 1). Additionally, we measured plant height (height of 1 plant randomly chosen within each transect). Transects were placed parallel to the coastline and in the middle of the spatial distribution of each marsh height at each study site. Given the characteristics of the shrub layer, we employed the quadrant samples method to estimate their vege- tation cover. All individuals were counted and measured (height, length and width) for each identified species within five $5 \times 5 \mathrm{~m}$ replicates in each habitat from every study site. Vegetation cover was calculated for each species in each replicate and for each layer. To describe $\alpha$-diversity, we calculated species richness and Shannon Wiener's diversity index (following Magurran 1988) in each replicate and for each layer. A Tukey's honestly significant difference (HSD) test following an analysis of variance (ANOVA; Zar 1999) was used to evaluate the null hypothesis of no differences in $\alpha$-diversity among sites. As community data are mainly multivariate (Clarke \& Warwick 2001), to test differences in marsh assemblages composition along the geographical gradient, multivariate analysis was used. To perform permutational analysis of variance (PERMANOVA), PRIMER 6 software was used (Clarke \& Gorley 2006). Bray-Curtis abundance similarity matrices (Clarke \& Warwick 2001) were constructed to test the multivariate null hypothesis of no differences in plant assemblage composition (species presence and abundance) among groups. Differences in plant assemblage compositions were tested between the different marsh elevations within each marsh and with the inland elevation (factor: low, high and inland) and between sites at the same habitat type (factor sites: $\mathrm{SC}, \mathrm{MCH}, \mathrm{BB}, \mathrm{BA}, \mathrm{RN}$ and $\mathrm{BSA}$ ). In order to obtain $p$-values $\left(p_{\text {perm }}\right)$, all PERMANOVA tests relied on 4999 permutations following the unrestricted raw data permutation method, which is the most appropriate for 1-way cases and provides a Type I error close to $\alpha$ (Anderson et al. 2008). A posteriori, pair-wise comparisons using 4999 random permutations were performed when PERMANOVA tests were significant at the 0.05 level. Plant assemblage composition was further explored using nonmetric multidimensional scaling ordination (NMDS), where a stress value $<0.20$ gives an adequate representation of the 2-dimensional NMDS (Clarke \& Warwick 2001).

To characterize the prevailing environmental conditions at each study site, we estimated some of the most important physical variables associated with plant growth: annual precipitation (O'Brien 2006, Eiserhardt et al. 2011, Canepuccia et al. 2010b), maximum, minimum and daily thermal amplitude (e.g. Speziale et al. 2010), and particularly important for marsh vegetation, salinity and tidal amplitude (Bertness et al. 1992, Pennings et al. 2005, Canepuccia et al. 2010b). Salinity of the water that floods the marshes daily can have strong effects on plant growth and development (e.g. Bertness et al. 1992, 
Canepuccia et al. 2010b). However, higher temperatures, sun radiation and evaporation can also enhance salinity in the water remaining in the marshes and in the sediment (e.g. Bertness et al. 1992, Fanjul et al. 2008), while rainfall can dilute their salinity (e.g. Canepuccia et al. 2010b). From each study site, the values of daily maximum (hereafter maximum temperature) and minimum temperatures (hereafter minimum temperature) from the nearest station of the Argentinean National Weather Service (Servicio Meteorológico Nacional Argentino; Fig. 1) were averaged for the years between 1990 and 2008. In a similar way, we estimated the mean daily thermal amplitude as the difference between the maximum and minimum temperatures for each day and for each station for the period from 1990 to 2008. Since BA did not have a close meteorological station, we estimated the climate variables by interpolation. To do that, we employed the meteorological stations located on the SW Atlantic coast among our study sites (Fig. 1) as data points to build our model. Then, we used the geostatistical kriging interpolation technique (Pardo-Iguzquiza 1998, Akkala et al. 2010) using latitude and longitude as independent variables to estimate the climate values for the BA location. Precipitation and tidal values for each study site were obtained from Isacch et al. (2006). Water salinity (hereafter salinity) values were measured (precision of $1 \%$ ) from 5 water samples at a distance of $50 \mathrm{~m}$ each, along the coastline during high tides at each marsh site in December, June and March. A Tukey's HSD test, following ANOVA (Zar 1999), was used to evaluate the null hypothesis of no differences in environmental conditions among sites. Then, by using a multiple regression model (Neter et al. 1990), we estimated the relationship between the environmental conditions (marsh area, precipitation, temperature, tidal amplitude and salinity) and plant characteristics (total plant cover, specific cover, species richness and diversity, and marsh-inland dissimilarity in species composition). Given that plant species interactions can also affect plant development (e.g. Bertness \& Hacker 1994, Bertness \& Ewanchuk 2002), the inter-specific coverage of plants for each habitat was also included in the regression model analysis. The variables were appropriately transformed to meet the assumptions of homogeneity of variance and normality of the residual error (Neter et al. 1990). A forward stepwise multiple regression analysis was used to optimize the model with lower complexity and higher explanatory capability (Neter et al. 1990). When the general model accepted multiple independent variables, we calculated the per- centage of the observed variance, explained by each independent variable. This was done using the coefficient $C_{i}=b_{i i} R_{i j}$, where $b_{i i}$ is the standardized partial regression coefficient of the independent variable $i$ and $R_{i j}$ is the correlation coefficient between this variable and the response variable $j$ (Fox \& Fox 2000).

\section{Physical characteristics driving species similarity between marshes and inland environment}

Similarity percentages (SIMPER) analysis was performed on plant abundance data to identify the species most responsible for the multivariate pattern. The SIMPER routine compares average abundance and examines the contribution of each species to dissimilarities (Clarke \& Warwick 2001) between marsh and inland vegetation along the SW Atlantic coast. A Monte Carlo analysis (Manly 1998) was used to evaluate the null hypothesis of no difference among sites in the marsh-inland dissimilarities in species composition. The analysis was made by a random resampling with replacement of the same number of interactions that the field observations performed (10 iterations) of plant composition in each habitat among all sites. For each iteration, we estimated dissimilarity percentages (SIMPER) analysis of plant composition. A Tukey's HSD test, following ANOVA (Zar 1999), was used to evaluate the null hypothesis of no differences among sites in the dissimilarity of communities between marsh-inland environments. As previously described, we used a multiple regression model (Neter et al. 1990) to estimate whether there is a relationship between environmental variables and marsh inland dissimilarity in species composition along the SW Atlantic coast. Forward stepwise multiple regression was used to remove redundant variables and to select the model with the lowest complexity and the highest explanatory capability (Neter et al. 1990). We calculated the percentage of the observed variance explained by each independent variable by means of the coefficient $C_{i}$ (Fox \& Fox 2000).

\section{RESULTS}

\section{Diversity of marsh-inland species composition and environmental conditions}

There were 29 plant species found during our sampling along the SW Atlantic coast (see Table S1 in 
the Supplement at www.int-res.com/ articles/suppl/m494p135_supp.pdf). Among them, only 4 species were found in marsh habitats (Spartina densiflora, $S$. perennis, the sea lavender Limonium brasiliense and the wild celery Apium commersonni). The plant assemblage composition (cover, richness and diversity; Table 1), as well as their tallness (Table S1 in the Supplement) varied among sampled sites. Plant assemblages changed between low and high marsh and among sites (Fig. 2). The low marsh was composed by monospecific stands of $S$. alterniflora, with the exception of $\mathrm{MCH}$, which was characterized by bare mudflat areas. Plant assemblage composition differed between sites $\left(p_{\text {perm }}=0.001\right)$. Posteriori pair-wise comparisons
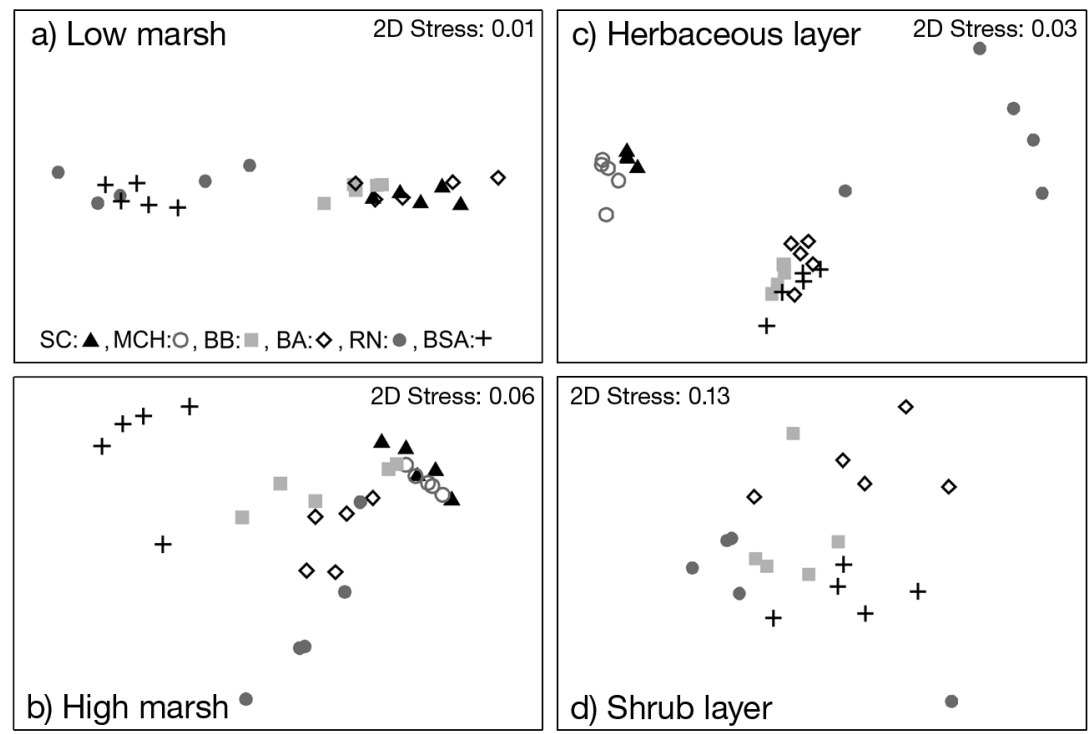

Fig. 2. Non-metric multidimensional scaling (NMDS) ordination plots using plant species abundance based on Bray-Curtis similarity matrices. Two-dimensional (2D) arrangements of sites (MCH, SC, BB, BA, RN and BSA, see Fig. 1 for details) are shown: (a) low marsh, (b) high marsh, (c) herbaceous layer and (d) shrub layer showed that the assemblage composition at $\mathrm{SC}$ was different from those at $\mathrm{BB}, \mathrm{RN}$ and BSA, while the assemblages at BB and BA differed from those at RN and BSA (Fig. 2a, NMDS). Environmental data (tidal amplitude, salinity, precipitation and temperature) changed among sites (Table 1). Forward stepwise multiple regression for the cover of $S$. alterniflora showed a positive association with logtransformed tidal range $(94.60 \%$ of the observed variance, $C=0.79$ ) and a negative relationship with salinity $(5.40 \%, C=0.05$; Table 2$)$. The tallness of

S. alterniflora stems showed a negative association with salinity (Table 2).

There was higher plant richness in the high marsh than in the lower marsh (up to 4 species), but only Spartina densiflora and S. perennis were dominant (Table S1 in the Supplement). It the high marsh, PERMANOVA performed on species coverage showed that the assemblage compositions of SC and $\mathrm{MCH}$ were different from those of $\mathrm{BB}, \mathrm{BA}, \mathrm{RN}$ and $\mathrm{BSA}_{i} \mathrm{BB}$ and $\mathrm{BA}$ differed from RN and BSA, and the

Table 1. Environmental data: tidal amplitude (m), salinity (\%), annual precipitation (mm), and maximum, minimum and thermal amplitudes $\left({ }^{\circ} \mathrm{C}\right)$ along the SW Atlantic coast. Temperature values for BA were obtained by geostatistical kriging interpolation using latitude and longitude as independent variables. $\alpha$-diversity: Shannon-Wiener index; $\beta$-diversity: marsh-inland dissimilarity. Different lowercase letters denote significant differences between sites at $\mathrm{p}<0.05$ with Tukey's honestly signif-

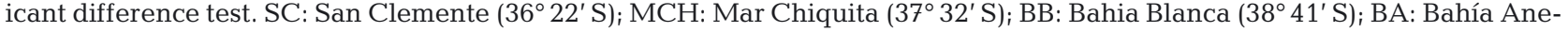

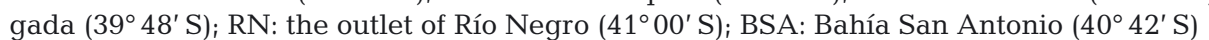

\begin{tabular}{|lcccccc|}
\hline & SC & MCH & BB & BA & RN & BSA \\
\hline Tidal amplitude & 0.75 & 0.79 & 2.44 & 1.64 & 2.94 & 6.44 \\
Salinity & $23.91(2.87)^{\mathrm{a}}$ & $27.95(1.04)^{\mathrm{b}}$ & $42.75(1.34)^{\mathrm{c}}$ & $38.17(1.02)^{\mathrm{d}}$ & $14.03(2.54)^{\mathrm{e}}$ & $40.30(1.12)^{\mathrm{f}}$ \\
Annual precipitation & 950 & 920 & 645 & 500 & 380 & 248 \\
Temperature & & & & & \\
$\quad$ Maximum & $34.09(1.25)^{\mathrm{a}}$ & $35.84(1.63)^{\mathrm{b}}$ & $38.81(1.77)^{\mathrm{c}}$ & 38.80 & $39.15(1.19)^{\mathrm{c}}$ & $38.21(9.32)^{\mathrm{d}}$ \\
Minimum & $-2.76(1.46)^{\mathrm{a}}$ & $-4.34(1.53)^{\mathrm{a}, \mathrm{b}}$ & $-5.85(2.03)^{\mathrm{b}, \mathrm{c}}$ & -6.11 & $-6.81(1.22)^{\mathrm{b}, \mathrm{c}}$ & $-6.58(4.46)^{\mathrm{c}}$ \\
Daily amplitude & $24.29(4.3)^{\mathrm{a}}$ & $24.19(1.77)^{\mathrm{a}}$ & $26.34(3.09)^{\mathrm{a}}$ & 27.02 & $27.51(1.85)^{\mathrm{a}, \mathrm{b}}$ & $28.33(8.10)^{\mathrm{b}}$ \\
a-diversity & & & & & & \\
High marsh & $0.28(0.20)^{\mathrm{b}, \mathrm{c}, \mathrm{d}}$ & $0.05(0.12)^{\mathrm{d}}$ & $0.47(0.28)^{\mathrm{a}, \mathrm{b}, \mathrm{e}}$ & $0.64(0.07)^{\mathrm{c}, \mathrm{e}}$ & $0.44(0.26)^{\mathrm{b}, \mathrm{c}, \mathrm{d}}$ & $0.85(0.20)^{\mathrm{a}, \mathrm{e}}$ \\
$\quad$ Herbaceous layer & $0.03(0.06)^{\mathrm{a}}$ & $1.07(0.30)^{\mathrm{b}}$ & $0.65(0.13)^{\mathrm{a}, \mathrm{b}}$ & $1.07(0.18)^{\mathrm{b}}$ & $0.89(0.58)^{\mathrm{b}}$ & $0.91(0.46)^{\mathrm{b}}$ \\
$\quad$ Shrub layer & & & $0.66(0.14)^{\mathrm{a}}$ & $0.98(0.05)^{\mathrm{b}}$ & $0.53(0.37)^{\mathrm{a}}$ & $0.66(0.01)^{\mathrm{a}}$ \\
$\beta$-diversity & $100.00(0.00)^{\mathrm{a}}$ & $89.84(3.95)^{\mathrm{b}}$ & $74.70(7.86)^{\mathrm{c}}$ & $75.92(6.64)^{\mathrm{c}}$ & $98.19(1.68)^{\mathrm{a}}$ & $66.89(4.57)^{\mathrm{d}}$ \\
\hline
\end{tabular}


Table 2. Forward stepwise multiple regression values between environmental variables and plant assemblage characteristics in marsh and inland areas along the SW Atlantic coast. Within each habitat, plant species and their characteristics are given: cover, tallness, $\alpha$-diversity (i.e. Shannon-Wiener index) and $\beta$-diversity (i.e. marsh-inland dissimilarity). ${ }^{*}: \mathrm{p}<0.05$. Final significant models were selected as functions of the environmental variables selected by the lowest corrected Akaike's information criterion for each step $\left(\mathrm{AIC}_{\mathrm{c}}\right)$. SSE: sum of squares due to error; RMSE: root mean square error

\begin{tabular}{|c|c|c|c|c|c|c|c|c|}
\hline Habitat variables & Parameter & Estimate & SS & $F$-ratio & SSE & RMSE & $\mathrm{R}^{2}$ & $\mathrm{AIC}_{\mathrm{C}}$ \\
\hline \multicolumn{9}{|l|}{ Low marsh } \\
\hline \multirow{3}{*}{ Spartina alterniflora } & Intercept & 13.39 & 0.00 & 0.00 & 222.68 & 2.87 & $0.84^{*}$ & 154.87 \\
\hline & Tidal range & 20.17 & 1160.74 & 140.74 & & & & \\
\hline & Salinity & -0.28 & 221.49 & 26.85 & & & & \\
\hline \multirow[t]{2}{*}{ Tallness } & Intercept & 105.37 & 0.00 & 0.00 & 3374.55 & 12.11 & $0.65^{*}$ & 200.71 \\
\hline & Salinity & -1.41 & 6057.41 & 41.29 & & & & \\
\hline \multicolumn{9}{|l|}{ High marsh } \\
\hline \multirow[t]{4}{*}{ Cover } & Intercept & 1.67 & 0.00 & 0.00 & 0.38 & 0.12 & $0.83^{*}$ & -33.55 \\
\hline & Salinity & -0.01 & 0.45 & 30.97 & & & & \\
\hline & Tidal range & -0.12 & 0.89 & 61.47 & & & & \\
\hline & Min. temperatures & -0.11 & 0.44 & 30.35 & & & & \\
\hline \multirow[t]{3}{*}{ Tallness } & Intercept & 2238.03 & 0.00 & 0.00 & 5774.21 & 14.62 & $0.80^{*}$ & 252.54 \\
\hline & Precipitation & 0.32 & 2861.73 & 13.38 & & & & \\
\hline & Thermal amplitude & -75.06 & 4852.58 & 22.69 & & & & \\
\hline \multirow[t]{4}{*}{ Richness } & Intercept & 2.07 & 0.00 & 0.00 & 6.76 & 0.51 & $0.38^{*}$ & 52.93 \\
\hline & Tidal range & 0.27 & 3.94 & 15.17 & & & & \\
\hline & Marsh area & $<0.001$ & 1.48 & 5.70 & & & & \\
\hline & Min. temperatures & 0.18 & 1.12 & 4.30 & & & & \\
\hline \multirow[t]{3}{*}{$\alpha$-diversity } & Intercept & 0.65 & 0.00 & 0.00 & 1.21 & 0.21 & $0.58^{*}$ & -1.47 \\
\hline & Salinity & 0.001 & 0.23 & 5.05 & & & & \\
\hline & Precipitation & $<-0.001$ & 1.15 & 25.59 & & & & \\
\hline \multirow[t]{5}{*}{ Spartina densiflora } & Intercept & -79.52 & 0.00 & 0.00 & 1193.03 & 6.91 & $0.84^{*}$ & 211.29 \\
\hline & Tidal range & -8.66 & 1713.53 & 35.91 & & & & \\
\hline & S. perennis & -0.44 & 1027.42 & 21.53 & & & & \\
\hline & Salinity & -0.63 & 599.21 & 12.56 & & & & \\
\hline & Thermal amplitude & 5.83 & 280.01 & 5.87 & & & & \\
\hline \multirow[t]{3}{*}{ Sarcocornia perennis } & Intercept & -1.31 & 0.00 & 0.00 & 5.28 & 0.44 & $0.72^{*}$ & 42.63 \\
\hline & Min. temperatures & -0.48 & 13.24 & 67.69 & & & & \\
\hline & Salinity & -0.02 & 0.89 & 4.57 & & & & \\
\hline \multirow[t]{3}{*}{ Limoium brasilense } & Intercept & 17.43 & 0.00 & 0.00 & 2.14 & 0.28 & $0.56^{*}$ & 15.56 \\
\hline & S. densiflora & -0.02 & 2.75 & 34.61 & & & & \\
\hline & Max. temperature & -10.75 & 1.17 & 14.75 & & & & \\
\hline Inland herbaceous laye & & & & & & & & \\
\hline Cover & Intercept & -1478.48 & 0.00 & 0.00 & 12122.99 & 21.19 & $0.57^{*}$ & 274.79 \\
\hline & Precipitation & $<0.001$ & 6257.54 & 13.94 & & & & \\
\hline & Thermal amplitude & 52.60 & 3964.31 & 8.83 & & & & \\
\hline Richness & Intercept & -25.97 & 0.00 & 0.00 & 0.52 & 0.14 & $0.66^{*}$ & -26.96 \\
\hline & Thermal amplitude & 0.90 & 0.69 & 35.88 & & & & \\
\hline & Precipitation & 0.005 & 0.58 & 30.05 & & & & \\
\hline$\alpha$-diversity & Intercept & -43.08 & 0.00 & 0.00 & 1.65 & 0.25 & $0.62^{*}$ & 7.77 \\
\hline & Thermal amplitude & 1.49 & 1.90 & 31.06 & & & & \\
\hline & Precipitation & 0.007 & 1.59 & 25.99 & & & & \\
\hline Cortadeira selloana & Intercept & -7.26 & 0.00 & 0.00 & 5658.49 & 14.22 & $0.75^{*}$ & 249.25 \\
\hline & Precipitation & $<0.001$ & 16566.75 & 81.98 & & & & \\
\hline S. perennis & Intercept & -23.78 & 0.00 & 0.00 & 7.48 & 0.52 & $0.32^{*}$ & 50.37 \\
\hline & Max. temperature & 15.31 & 3.46 & 12.97 & & & & \\
\hline L. brasilense & Intercept & 0.47 & 0.00 & 0.00 & 6.83 & 0.49 & $0.28^{*}$ & 47.65 \\
\hline & Precipitation & $<-0.001$ & 2.67 & 10.97 & & & & \\
\hline Frankenia juniperoides & Intercept & 2.11 & 0.00 & 0.00 & 12.55 & 0.67 & $0.26^{*}$ & 65.92 \\
\hline & Precipitation & -0.07 & 4.44 & 9.90 & & & & \\
\hline Inland shrub layer & & & & & & & & \\
\hline Cover & Intercept & 0.04 & 0.00 & 0.00 & 0.17 & 0.08 & $0.80^{*}$ & -62.46 \\
\hline & Precipitation & $<0.001$ & 0.70 & 112.33 & & & & \\
\hline Richness & Intercept & -24.84 & 0.00 & 0.00 & 9.26 & 0.58 & $0.85^{*}$ & 56.80 \\
\hline & Max. temperature & 0.71 & 53.44 & 161.58 & & & & \\
\hline$\alpha$-diversity & Intercept & -21.60 & 0.00 & 0.00 & 2.73 & 0.31 & $0.73^{*}$ & 20.17 \\
\hline & Precipitation & 0.00 & 0.13 & 1.33 & & & & \\
\hline & Max. temperature & 3.04 & 7.39 & 75.73 & & & & \\
\hline Atriplex lampa & Intercept & 0.14 & 0.00 & 0.00 & 10.61 & 0.62 & $0.80^{*}$ & 60.87 \\
\hline & Precipitation & 0.005 & 43.16 & 113.93 & & & & \\
\hline Cyclolepis genistoides & Intercept & -0.25 & 0.00 & 0.00 & 4.06 & 0.38 & $0.53^{*}$ & 32.03 \\
\hline & Precipitation & -0.001 & 4.55 & 31.42 & & & & \\
\hline$\beta$-diversity & Intercept & 43906.29 & $<0.01$ & $<0.01$ & $3.56^{\mathrm{E}+07}$ & 776.37 & $0.89^{*}$ & 975.80 \\
\hline & Salinity & -182.54 & $1.74^{\mathrm{E}+08}$ & 287.89 & & & & \\
\hline & Precipitation & $<-0.01$ & $2.84^{\mathrm{E}+06}$ & 4.73 & & & & \\
\hline & Thermal amplitude & -1142.38 & $9.72^{\mathrm{E}+06}$ & 16.13 & & & & \\
\hline
\end{tabular}


plant assemblage composition at RN was different from that at BSA ( $p_{\text {perm }}=0.001$; Fig. $2 b$, NMDS). The total plant cover (log transformed) showed a negative association with tidal amplitudes $(60.75 \%, C=0.57)$, with salinity $(33.16 \%, C=0.31)$ and with the mean daily minimum temperatures $(9.09 \%, C=0.06$; Table 2). Plant tallness was negatively associated with the mean daily thermal amplitude $(57.86 \%, C=2.93)$ and positively associated with precipitation $(42.14 \%$, $C=2.14$; Table 2). Plant richness was positively associated with tidal range $(84.01 \%, C=0.32)$ and with the surface of the high marsh $(15.90 \%, C=0.06)$ and was negatively associated with minimum temperature $(0.10 \%, C<0.10$; Table 2$)$. Species diversity showed a positive association with salinity $(20.82 \%$, $C=0.12$ ) and a negative association with precipitation $(79.18 \%, C=0.46$; Table 2). $S$. densiflora was one of the dominant plant species in the high marsh; its cover was negatively associated with tidal amplitudes $(69.72 \%, C=0.87)$, with $S$. perennis cover $(19.42 \%, C=0.24)$, with salinity $(9.89 \%, C=0.12)$ and with thermal amplitude $(0.97 \%, C=0.01$; Table 2). Sarcocornia perennis is another dominant plant species in the high marsh. Its cover (log transformed) showed a negative association with daily minimum temperature $(98.98 \%, C=0.71)$ and with salinity $(1.02 \%, C=0.01$; Table 2$)$. The logtransformed cover of the companion species Limoium brasilense showed a negative association with S. densiflora cover $(91.30 \%, C=0.52)$ and with logtransformed daily maximum temperature $(8.70 \%$, $C=0.05$; Table 2).

Inland, the northern sites ( $\mathrm{SC}$ and $\mathrm{MCH}$ ) were characterized by an herbaceous layer dominated by the silver pampas grass Cortaderia selloana, while the presence of a shrub layer characterized the southern sites belonging to the provinces of the Monte and Espinal. At the herbaceous layer, plant assemblage compositions differed between sites $\left(p_{\text {perm }}=0.001\right)$, except between BA and BSA $\left(p_{\text {perm }}=\right.$ 0.08 ; Fig. 2c, NMDS). The selected model for herbaceous plant cover included a positive association with precipitation (squared transformed, $58.19 \%, C=$ 2.04) and a negative association with the thermal amplitude $(41.81 \%, C=1.46$; Table 2). Richness (log transformed) showed a positive association with the thermal amplitude $(56.12 \%, C=0.52)$ and a negative association with precipitation $(43.88 \%, C=2.35$; Table 2), while $\alpha$-diversity (Shannon-Wiener index root transformed) showed a positive association with thermal amplitude $(56.11 \%, C=2.87)$ and a negative association with precipitation $(43.89 \%, C=-2.24$; Table 2). At the herbaceous layer, C. selloana cover showed a positive association with precipitation (Table 2). The log-transformed cover of Sarcocornia perennis was positively associated with maximum temperatures (Table 2). The log cover of both of Limoium brasilense and the juniperoid seaheath Frankenia juniperoides was negatively associated with precipitation (Table 2).

At the shrub layer, the compositions of plant assemblages differed between sites $\left(p_{\text {perm }}=0.003\right)$, showing similarity between $\mathrm{RN}$ and BSA $\left(\mathrm{p}_{\text {perm }}=\right.$ 0.19 ) and between BB and RN ( $p_{\text {perm }}=0.80$; Fig. $2 d$, NMDS). Yet, the shrub layer showed similar species compositions between sites located in both biogeographic provinces (Espinal and Monte), being dominated by the saltbush species Atriplex lampa and Cyclolepis genistoides and the chuquiragua Chuquiraga erinacea, with the exception of $\mathrm{BA}$, where the importance of C. erinacea increased (Fig. 2d). Plant coverage (log transformed) in the shrub layer showed a negative association with the Box-Cox transformation (theta $=4.6$ ) of precipitation (Table 2). Both richness and $\alpha$-diversity (Table 2) showed a positive association with the maximum temperature. The Box-Cox transformation of the covers of Atriplex lampa (theta $=0.23$; Table 2), and Cyclolepis genistoides (theta $=0.56$; Table 2 ) showed negative associations with precipitation.

\section{Environmental characteristics associated with species dissimilarity between marshes and inland area}

At $\mathrm{MCH}$, SIMPER analysis revealed that 4 species contributed more than two-thirds of the average Bray-Curtis dissimilarity (91.8\%) between high marsh and inland. Cortaderia selloana $(42.5 \%)$, Spartina densiflora $(32.5 \%)$, the tussock paspalum Paspalum quadrifarium (12.9\%) and Stipa sp. (8.1\%) were the species most responsible for the differences among groups. C. selloana, P. quadrifarium and Stipa sp. were only present in the inland area, while $S$. densiflora was registered inland and in the high marsh but with a higher abundance (10-fold) in the latter. SIMPER analysis showed that 2 species explained most of the average dissimilarity $(100 \%)$ among high marsh and inland vegetation at SC. These species were C. selloana (51.6\%) and S. densiflora (44.3\%). The former was only present in the inland area, while the latter was registered only in the high marsh (Fig. S1a,b in the Supplement at www.int-res.com/ articles/suppl/m494p135_supp.pdf).

At $\mathrm{BB}$, the average dissimilarity between high marsh and inland vegetation was $75.9 \%$, with only 3 
species accounting for $>99 \%$ of the dissimilarity among groups. Spartina densiflora contributed $47.2 \%$, Frankemia juniperoides $40.2 \%$ and Sarcocornia perennis $12 \%$. Spartina densiflora was only registered in the high marsh ${ }_{i} F$. juniperoides, in the inland area; and $S$. perennis was present at both locations. The results of the SIMPER analysis at BA showed that 4 plant species contributed most to dissimilarities among high marsh and inland vegetation $(75.5 \%)$, with $S$. densiflora $(44.9 \%), S$. perennis $(22.3 \%)$, Limoium brasiliense $(17.4 \%)$ and $F$. juniperoides $(15.3 \%)$ being the highest contributors. S. densiflora and $S$. perennis were present at both sites, but their average abundance was higher (29- and 3-fold, respectively) in the high marsh than in the inland area. $L$. brasiliense and F. juniperoides were only registered in the inland area.

High average dissimilarity was noted between high marsh and inland vegetation $(98.3 \%)$ at $\mathrm{RN}$, with only 2 species contributing $>90 \%$ of that difference. Spartina densiflora was only registered in the high marsh, while Sarcocornia perennis was present in both areas but with a higher abundance in the high marsh (60-fold higher). S. densiflora was only registered in the high marsh. At BSA, SIMPER analysis showed that 4 species, Frankenia juniperoides $(63 \%), \quad$ S. perennis $(12.2 \%)$, Limoium brasiliense $(12.2 \%)$ and the spreading alkaliweed Cressa truxillensis $(7.2 \%)$, contributed $>95 \%$ of the average dissimilarity $(68.5 \%)$ between the high marsh and the inland areas. F. juniperoides and C. truxillensis were only present in the inland area, while $S$. perennis and L. brasiliense were in both areas with higher abundance in the high marsh (Fig. S1d,e in the Supplement). The model selected by forward stepwise multiple regression for plant dissimilarity (squared transformed) between marsh and inland areas, included a negative association with salinity $(59.90 \%$, $C=0.73)$, with a thermal amplitude $(16.71 \%, C=$ 0.22 ), and a positive association with Box-Cox transformation (theta $=3.3$ ) of precipitation $(28.38 \%, C=$ 0.38 ; Table 2).

\section{DISCUSSION}

Along our studied geographic range, tidal marshes showed a monoculture of Spartina alterniflora in the low marsh and higher plant diversity (mainly Spartina densiflora and Sarcocornia perennis) in the high marsh. The abundance, dominance, richness and diversity of marsh plants changed with latitude. In the lower marsh, plant cover increased, while its tall- ness decreased in association with tidal range and salinity. In the high marsh, plant cover and tallness decreased, while plant richness and diversity increased in association with tide ranges, salinity, minimum temperatures and with a decrease in precipitation. Inland, plant cover decreased, while its richness and diversity increased in association with minimum temperature, thermal amplitude and with a decrease in precipitation. Additionally, the dissimilarity in plant species compositions ( $\beta$-diversity) between marsh and inland assemblages decreased in association with salinity, thermal amplitude and with a decrease in precipitation.

The low marsh elevations were inhabited by a monoculture of Spartina alterniflora, with the exception of $\mathrm{MCH}$, which was characterized by bare mudflat areas. Southwards, along our study range, the cover of $S$. alterniflora increases in association with oceanic influences expressed in higher salinity and tidal ranges, while its tallness decreases in association with increased salinity. Waterlogging is stressful to angiosperms due to increasing soil anoxia (Callaway et al.1990, Huckle et al. 2000, Pennings \& Bertness 2001). Moreover, the tidal flushing and subsequent evaporation increase the salinity of marsh sediments (Bertness et al. 1992, Fanjul et al. 2008). Along the SW Atlantic coast, marshes such as BB and BSA showed much higher salinity values than seawater $(>40 \%$ ). This hypersaline condition may be due to the fact that these marshes are exposed to larger tidal ranges (Isacch et al. 2006). Moreover, evaporation and restricted circulation, which are characteristic of $\mathrm{BB}$ and BSA, contribute to the increase in water salinity at these sites (Perillo et al. 2006). The toxicity of $\mathrm{Na}^{+}$ and $\mathrm{Cl}^{-}(\mathrm{Hu} \&$ Schmidhalter 2005) reduces plant growth and survival (Cavalieri \& Huang 1981, Hu \& Schmidhalter 2005, Canepuccia et al. 2010b), which can result in lower plant height. Similar patterns of higher $S$. alterniflora density, but shorter stems in zones with less favorable conditions, have been reported for local (Turner 1976, Reimold 1977, Seliskar et al. 2002) and geographic gradients in marsh environmental severity (Seliskar et al. 2002). These intraspecific differences between plant heights and densities may be the result of non-competitive neighbors becoming competitors under favorable conditions (Bertness \& Ewanchuk 2002). Thus, it is possible that, at lower latitude sites, the above-ground competition for light modulates the outcome of plant interactions (e.g. Levine et al. 1998, Emery et al. 2001), resulting in taller stems but lower densities of plants than at higher latitudes, which experience greater environmental severity. As a result, the plant coverage here 
changed with environmental harshness, resulting in 2 major types of landscapes: northern sites, characterized by a lower cover of and taller $S$. alterniflora, and the southern sites, characterized by higher cover and shorter stems.

In the high marsh, cover and tallness of plants decreased in association with oceanic harshness (tidal range and salinity), as well as with minimum temperature, thermal amplitude and a decrease in precipitation. Precipitation is an important component of the water availability for plants (O'Brien 1998). In addition, precipitation dilutes salt in the high marsh (Canepuccia et al. 2010b), where salt stress is greater than in the low marsh due to irregular tidal flushing and high evaporation (e.g. Bertness et al. 1992). Moreover, given that warmer mean temperature and more stable climate favors plant development (Currie et al. 2004, Evans et al. 2005, Clarke \& Gaston 2006), the exposure to lower temperatures (Hatcher \& Mann 1975, Mendelssohn \& Morris 2002, Kirwan et al. 2009) and a higher daily thermal amplitude (Speziale et al. 2010) can have negative effects on plant growth (Clarke \& Gaston 2006). Thus, due to the fact that environmental stressors (aridity, lower temperatures and daily thermal amplitude) increase southwards along the SW Atlantic coast, marsh plants seem to respond by reducing their coverage and height southward. However, the responses differed between the 2 dominant species in the high marsh. While the cover of Spartina densiflora decreased, the cover of Sarcocornia perennis increased in association with salinity, tidal range and a precipitation decrease southwards. $\mathrm{C}_{3}$ plants (i.e. S. perennis) are able to maintain higher photosynthetic performance across wider temperature ranges than co-occurring $\mathrm{C}_{4}$ (i.e. $S$. densiflora) grasses (BarronGafford et al. 2012). Also, $C_{3}$ plants have deeper rooting systems, which allow them to use groundwater better than $\mathrm{C}_{4}$ grasses (Hultine et al. 2004, BarronGafford et al. 2012). Therefore, it is possible that $S$. perennis $\left(\mathrm{C}_{3}\right)$ outcompetes $S$. densiflora $\left(\mathrm{C}_{4}\right)$ in harsher marshes. Due to either variation in the environmental conditions or in the trade-off between competitive ability and stress tolerance capacity of each species (Grime 1977, Pennings \& Bertness 1999; see Idaszkin et al. 2011 for discussion of these species), there is a replacement of the dominance of $S$. densiflora by $S$. perennis southward, while a mixture of both species characterized the middle sites.

Inland, plant species varied in abundance, diversity and dominance, and they also varied in species constitution, changing across different biogeographic provinces (Cabrera \& Willink 1973). The pres- ence of a shrub layer characterized the southern inland sites belonging to the Monte and Espinal provinces (Cabrera \& Willink 1973). However, we found vegetation typical of the Monte province located in the marshes of BB and BA, where according to the literature (see Cabrera \& Willink 1973, our Fig. 1), we were expecting plants typical of the Espinal province. This may be either because the coastal area of the Espinal province has receded or has been invaded by the Monte province, or just because the coastal area has always been dominated by Monte province vegetation, a pattern that has not been detected by previous studies. Each inland layer shows different responses to environmental harshness. The cover and tallness of the herbaceous layer (mainly grasses) increased with increased precipitation and decreased with thermal amplitude while the cover of the shrubs layer showed the opposite pattern, appearing where annual precipitation was $<600 \mathrm{~mm}$ in $\mathrm{BB}\left(39^{\circ} \mathrm{S}\right)$. These differences between plant layers may be associated, at least in part, with the fact that grasses have shallow root systems that are capable of responding rapidly to increased soil humidity (Soriano \& Sala 1984). In contrast, shrubs are more tolerant of wider temperature ranges (Barron-Gafford et al. 2012), and their deeper roots allow them to use water from deeper soil layers than those that can be used by grasses in dry environments (Soriano \& Sala 1984, Speziale et al. 2010, BarronGafford et al. 2012). Although we cannot exclude the fact that the inverse relationship between these layers in the biogeography of the SW Atlantic are mediated by competition (e.g. Sommer \& Worm 2002), the changes in environmental factors here seem to establish the proximate limit between the grassland and shrub landscapes along the SW Atlantic coast.

As expected for the species/area relationship (e.g. MacArthur \& Wilson 1967, Rosenzweig 1995, Lawton 1999), there was a positive relationship between the surface of the high marsh and species richness along the SW Atlantic coast. However, although it has been postulated that plant richness decreases with environmental severity (e.g. gradients in salinity: Adams 1963, Odum 1988; water availability: Hawkins et al. 2003, Clarke \& Gaston 2006, Speziale et al. 2010; and daily thermal amplitude: Clarke \& Gaston 2006, Speziale et al. 2010), we found the opposite pattern. At high marsh elevation, species richness increased in association with tidal range, and plant $\alpha$-diversity increased with salinity and decreased with precipitation. In addition, the number of layers increased from 1 herbaceous layer in the wet northern sites to 2 (herbaceous and shrub layers) in the drier southern 
ones. Indeed, the richness and $\alpha$-diversity of both layers decreased with precipitation, while the richness and $\alpha$-diversity of the herbaceous layer increased with the thermal amplitude. These positive relationships between $\alpha$-diversity and environmental severity could be due to the fact that the higher the level of stress (e.g. desiccation, heat, salinity), the lower the importance of negative interactions (e.g. competence), while the importance of the positive ones (e.g. facilitation) can increase (stress-gradient hypothesis: Bertness \& Callaway 1994, Callaway \& Walker 1997, Bertness \& Ewanchuk 2002), promoting high biodiversity. This trade-off between positive and negative plant interactions has been reported for aridity gradients among desert shrubs (Guo \& Berry 1998), between desert shrubs and annual species (Holzapfel et al. 2006) and along temperature gradients in alpine environments (Callaway et al. 2002). Our study, extending almost to the southern distribution limit of Spartina spp. marshes $\left(41^{\circ} \mathrm{S}\right.$ : Isacch et al. 2006, Bortolus et al. 2009), suggests that, among these environments, the $\alpha$-diversity also increases with environmental severity.

As plant $\alpha$-diversity increases with environmental severity, marsh-inland dissimilarity in species composition also decreases. Although a decrease in $\beta$-diversity with latitude is generally expected (e.g. Qian \& Ricklefs 2007, Qian 2008, 2009, Rodríguez \& Arita 2004, Qian et al. 2009, Hof et al. 2008), there have been mixed results, and knowledge on $\beta$-diversity changes related to geography is scarce (e.g. see Koleff et al. 2003, Tscharntke et al. 2012 and references therein). One idea that has received support is that more benign habitats may promote the coexistence of specialist species (Speziale et al. 2010) with a higher degree of resource competition (Tilman 1982, Grime 2001, Harrison et al. 2006), which could prevent species turnover between habitats. In contrast, organisms living in a highly constraining environment may require a more generalist physiology and ecology (Stevens 1989) to be able to become more widespread throughout the landscape (Stevens 1989, Clarke \& Gaston 2006). Likewise, along the SW Atlantic coast, the shared species between the low-diversity marshes and the inland vegetation seem to increase with environmental severity, supporting the idea that the landscape effects on species composition of habitat ('landscape-divergence hypothesis': Laurance et al. 2007, Tscharntke et al. 2012) change with geographic gradients in environmental conditions.

Community composition is commonly seen as being regulated by filters, including environmental conditions and biological interactions (e.g. Grime 1998,
Lortie et al. 2004). Here, we present evidence that environmental filters that influence plant assemblages vary according to geography, highlighting the need of considering the scale-specific influence of processes on $\alpha$ - and $\beta$-diversity patterns. Given the fact that the impact of each filter is not fixed, an insight into their relative effects on species distribution and diversity according to geography is critical for understanding the accelerated loss of biodiversity in a changing world (Sodhi \& Ehrlich 2010, Tscharntke et al. 2012). Here, either the decrease in species diversity or the higher specialization of species living in less harsh environmental conditions seems to prevent similarities of communities among marsh-inland environments. As a result, communities that develop in more benign conditions, by decreasing their similarity, could help secure regional biodiversity, therefore reconciling their low local diversity by increasing landscape heterogeneity at geographic scales.

Acknowledgements. We are very grateful to L. Cermelo, M. Kittlein and M. Tonello for help with temperature data analysis and M. S. Fanjul, C. Khatchikian, R. Osman and 3 anonymous reviewers for their valuable suggestions and corrections on an early version of the manuscript. This work was supported by grants from the Universidad Nacional de Mar del Plata, Consejo Nacional de Investigaciones Científicas y Técnicas (CONICET) and the Agencia Nacional de Promoción Científica y Tecnológica (all to O.O.I)

\section{LITERATURE CITED}

Adams DA (1963) Factors influencing vascular plant zonation in North Carolina salt marshes. Ecology 44:445-456

> Akkala A, Devabhaktuni V, Kumar A (2010) Interpolation techniques and associated software for environmental data. Environ Prog Sustain Energy 29:134-141

> Alberti J, Escapa M, Daleo P, Iribarne OO, Silliman B, Bertness $M$ (2007) Local and geographic variation in grazing intensity by herbivorous crabs in SW Atlantic salt marshes. Mar Ecol Prog Ser 349:235-243

Andersen KM, Endara MJ, Turner BL, Bailing JW (2012) Trait-based community assembly of understory palms along a soil nutrient gradient in a lower montane tropical forest. Oecologia 168:519-531

Anderson MJ, Gorley RN, Clarke KR (2008) PERMANOVA+ for PRIMER: guide to software and statistical methods. PRIMER-E, Plymouth

> Andrew ME, Wulder MA, Coops NC, Baillargeon G (2012) Beta-diversity gradients of butterflies along productivity axes. Glob Ecol Biogeogr 21:352-364

Balech E, Ehrlich MD (2008) Esquema biogeográfico del Mar Argentino. Rev Invest Des Pesq 19:45-75

> Barron-Gafford GA, Scott RL, Jenerette GD, Hamerlynck EP, Huxman TE (2012) Temperature and precipitation controls over leaf- and ecosystem-level $\mathrm{CO}_{2}$ flux along a woody plant encroachment gradient. Glob Change Biol $18: 1389-1400$ 
Bertness MD (1991) Zonation of Spartina patens and Spartina alterniflora in a New England salt marsh. Ecology 72:138-148

Bertness MD, Callaway R (1994) Positive interactions in communities. Trends Ecol Evol 9:191-193

Bertness MD, Ewanchuk PJ (2002) Latitudinal and climatedriven variation in the strength and nature of biological interactions in New England salt marshes. Oecologia 132:392-401

> Bertness MD, Hacker SD (1994) Physical stress and positive associations among plants. Am Nat 144:363-372

> Bertness MD, Gough L, Shumway SW (1992) Salt tolerances and the distribution of plants across a New England salt marsh. Ecology 73:1842-1851

> Bortolus A, Schwindt E, Bouza PJ, Idaszkin YL (2009) A characterization of Patagonian salt marshes. Wetlands 29:772-780

Boschi EE (2000) Species of decapod crustaceans and their distribution in the American marine zoogeographic provinces. Rev Invest Des Pesq 13:1-136

Cabrera AL (1976) Regiones fitogeografías de la República Argentina. Editorial ACME, Buenos Aires

Cabrera AL, Willink A (1973) Biogeografía de América Latina. Serie de biología, monográfica No. 13. Programa regional de Desarrollo Científico y Tecnológico, Departamento de Asuntos Científicos, Organización de Estados Americanos, Washington, DC

> Callaway RM, Walker LR (1997) Competition and facilitation: a synthetic approach to interactions in plant communities. Ecology 78:1958-1965

> Callaway RM, Jones S, Ferren WR Jr, Parikh A (1990) Ecology of a Mediterranean-climate estuarine wetland at Carpinteria, California: plant distributions and soil salinity in the upper marsh. Can J Bot 68:1139-1146

Callaway RM, Brooker RW, Choler P, Kikvidze Z and others (2002) Positive interactions among alpine plants increase with stress. Nature 417:844-848

> Canepuccia AD, Alberti J, Daleo P, Pascual J, Farina JL, Iribarne OO (2010a) Ecosystem engineering by burrowing crabs increases cordgrass mortality caused by stemboring insects. Mar Ecol Prog Ser 404:151-159

> Canepuccia AD, Alberti J, Pascual J, Alvarez G, Cebrian J, Iribarne OO (2010b) ENSO episodes modify plant/terrestrial-herbivore interactions in a southwestern Atlantic salt marsh. J Exp Mar Biol Ecol 396:42-47

> Canepuccia AD, Montemayor D, Pascual J, Farina JL, Iribarne OO (2011) A stem-boring moth drives detritus production in SW Atlantic marshes. Mar Ecol Prog Ser 442:1-9

Canfield R (1941) Application of line interception in sampling range vegetation. J For 39:388-394

> Cavalieri AJ, Huang AH (1981) Accumulation of proline and glycinebetaine in Spartina alterniflora Loisel in response to $\mathrm{NaCl}$ and nitrogen in the marsh. Oecologia 49: 224-228

Clarke A, Gaston KJ (2006) Climate, energy and diversity. Proc R Soc Lond B 273:2257-2263

Clarke KR, Gorley RN (2006) PRIMER v6: user manual/tutorial. PRIMER-E, Plymouth

Clarke KR, Warwick RM (2001) Change in marine communities: an approach to statistical analysis and interpretation, 2nd edn. PRIMER-E, Plymouth

Currie DJ, Mittelbach GG, Cornell HV, Field R and others (2004) Predictions and tests of climate-based hypotheses of broad-scale variation in taxonomic richness. Ecol Lett 7:1121-1131
Eiserhardt WL, Bjorholm S, Svenning JC, Rangel TF, Balslev $H$ (2011) Testing the water-energy theory on American palms (Arecaceae) using geographically weighted regression. PLoS ONE 6:e27027

- Emery NC, Ewanchuk PJ, Bertness MD (2001) Competition and salt-marsh plant zonation: stress tolerators may be dominant competitors. Ecology 82:2471-2485

Evans KL, Warren PH, Gaston KJ (2005) Species-energy relationships at the macroecological scale: a review of the mechanisms. Biol Rev Camb Philos Soc 80:1-25

Fanjul EM, Grela A, Canepuccia AD, Iribarne OO (2008) The Southwest Atlantic intertidal burrowing crab Neohelice granulata modifies nutrient loads of phreatic waters entering coastal area. Estuar Coast Shelf Sci 79: 300-306

Fox BJ, Fox MD (2000) Factors determining mammal species richness on habitat islands and isolates: habitat diversity, disturbance, species interactions and guild assembly rules. Glob Ecol Biogeogr 9:19-37

> Grime JP (1977) Evidence for the existence of three primary strategies in plants and its relevance to ecological and evolutionary theory. Am Nat 111:1169-1194

> Grime JP (1998) Benefits of plant diversity to ecosystems: immediate, filter and founder effects. J Ecol 86:902-910

Grime JP (2001) Plant strategies, vegetation processes, and ecosystem properties, 2nd edn. Wiley \& Sons, Chichester

$>$ Guo Q, Berry WL (1998) Species richness and biomass: dissection of the hump-shaped relationship. Ecology 79: 2555-2559

> Harrison S, Davies KF, Safford HD, Viers JH (2006) Beta diversity and the scale-dependence of the productivitydiversity relationship: a test in the Californian serpentine flora. J Ecol 94:110-117

> Hatcher BG, Mann KH (1975) Above-ground production of marsh cordgrass (Spartina alterniflora) near the northern end of its range. J Fish Res Board Can 32:83-87

> Hawkins BA, Field R, Cornell HV, Currie DJ and others (2003) Energy, water, and broad-scale geographic patterns of species richness. Ecology 84:3105-3117

> Hillebrand H (2004) On the generality of the latitudinal diversity gradient. Am Nat 163:192-211

Hof C, Brändle M, Brandl R (2008) Latitudinal variation of diversity in European freshwater animals is not concordant across habitat types. Glob Ecol Biogeogr 17: 539-546

Holzapfel C, Tielbörger K, Parag HA, Kigel J, Sternberg M (2006) Annual plant-shrub interactions along an aridity gradient. Basic Appl Ecol 7:268-279

Hu Y, Schmidhalter U (2005) Drought and salinity: a comparison of their effects on mineral nutrition of plants. J Plant Nutr Soil Sci 168:541-549

Huckle JM, Potter JA, Marrs RH (2000) Influence of environmental factors on the growth and interactions between salt marsh plants: effects of salinity, sediment and waterlogging. J Ecol 88:492-505

> Hultine KR, Scott RL, Cable WL, Goodrich DC, Williams DG (2004) Hydraulic redistribution by a dominant, warmdesert phreatophyte: seasonal patterns and response to precipitation pulses. Funct Ecol 18:530-538

> Idaszkin YL, Bortolus A, Bouza PJ (2011) Ecological processes shaping Central Patagonian salt marsh landscapes. Austral Ecol 36:59-67

Isacch JP, Costa CSB, Rodríguez-Gallego L, Conde D, Escapa M, Gagliardini DA, Iribarne OO (2006) Distribution of saltmarsh plant communities associated with 
environmental factors along a latitudinal gradient on the south-west Atlantic coast. J Biogeogr 33:888-900

Keddy PA (1992) Assembly and response rules: two goals for predictive community ecology. J Veg Sci 3:157-164

> Kirwan ML, Guntenspergen GR, Morris JT (2009) Latitudinal trends in Spartina alterniflora productivity and the response of coastal marshes to global change. Glob Change Biol 15:1982-1989

Koleff P, Lennon JJ, Gaston KJ (2003) Are there latitudinal gradients in species turnover? Glob Ecol Biogeogr 12: 483-498

> Laurance WF, Nascimento HEM, Laurance SG, Andrade A and others (2007) Habitat fragmentation, variable edge effects, and the landscape-divergence hypothesis. PLoS ONE 2:e1017

Lawton JH (1999) Are there general laws in ecology? Oikos 84:177-192

> Levine JM, Brewer JS, Bertness MD (1998) Nutrients, competition and plant zonation in a New England salt marsh. J Ecol 86:285-292

Lortie CJ, Brooker RW, Choler P, Kikvidze Z, Michalet R, Pugnaire FI, Callaway RM (2004) Rethinking plant community theory. Oikos 107:433-438

MacArthur RH, Wilson EO (1967) The theory of island biogeography. Monographs in population biology. Princeton University Press, Princeton, NJ

Magurran AE (1988) Ecological diversity and its measurement. Princeton University Press, Princeton, NJ

Manly BFJ (1998) Randomization, bootstrap and Monte Carlo methods in biology, 2nd edn. Chapman \& Hall Press, London

Mendelssohn I, Morris J (2002) Eco-physiological controls on the productivity of Spartina alterniflora Loisel. In: Weinstein MP, Kreeger DA (eds) Concepts and controversies in tidal marsh ecology. Kluwer Academic Publishers, Dordrecht, p 59-80

Mitsch WJ, Gosselink JG (1993) Wetlands, 2nd edn. Wiley \& Sons, New York, NY

Neter J, Wassermann W, Kutner MH (1990) Applied linear statistical models: regression, analysis of variance, and experimental designs, 3rd edn. Irwin, Homewood, IL

O'Brien EM (1998) Water-energy dynamics, climate, and prediction of woody plant species richness: an interim general model. J Biogeogr 25:379-398

O'Brien EM (2006) Biological relativity to water-energy dynamics. J Biogeogr 33:1868-1888

Odum WE (1988) Comparative ecology of tidal freshwater and salt marshes. Annu Rev Ecol Evol Syst 19:147-176

Pardo-Iguzquiza E (1998) Comparison of geostatistical methods for estimating the areal average climatological rainfall mean using data on precipitation and topography. Int J Climatol 18:1031-1047

Pennings SC, Bertness MD (1999) Using latitudinal variation to examine effects of climate on coastal salt marsh pattern and process. Curr Topics Wetland Biogeochem 3: 100-111

Pennings SC, Bertness MD (2001) Salt marsh communities. In: Hay ME (ed) Marine community ecology. Sinauer Associates, Sunderland, MA, p 289-316

> Pennings SC, Grant MB, Bertness MD (2005) Plant zonation in low-latitude salt marshes: disentangling the roles of flooding, salinity and competition. J Ecol 93:159-167

Pennings SC, Zimmer M, Dias N, Sprung $M$ and others (2007) Latitudinal variation in plant-herbivore interactions in European salt marshes. Oikos 116:543-549
Pennings SC, Ho CK, Salgado CS, Wieski K, Dave N, Kunza AE, Wason EL (2009) Latitudinal variation in herbivore pressure in Atlantic coast salt marshes. Ecology 90: 183-195

Perillo GME, Piccolo MC, Marcovecchio J (2006) Coastal oceanography of the western south Atlantic continental shelf $\left(33\right.$ to $\left.55^{\circ} \mathrm{S}\right)\left(5^{\circ} \mathrm{W}\right)$. In: Robinson AR, Brink KH (eds) The sea, ideas and observations on progress in the study of the seas: the global coastal ocean. Interdisciplinary regional studies and syntheses. Harvard University Press, Boston, MA, p 295-328

Qian H (2008) A latitudinal gradient of beta diversity for exotic vascular plant species in North America. Divers Distrib 14:556-560

> Qian H (2009) Beta diversity in relation to dispersal ability for vascular plants in North America. Glob Ecol Biogeogr 18:327-332

Qian H, Ricklefs RE (2007) A latitudinal gradient in largescale beta diversity for vascular plants in North America. Ecol Lett 10:737-744

Qian H, Badgley C, Fox DL (2009) The latitudinal gradient of beta diversity in relation to climate and topography for mammals in North America. Glob Ecol Biogeogr 18: 111-122

Reimold RJ (1977) Mangals and salt marshes of eastern United States. In: Chapman VJ (ed) Wet coastal ecosystems. Elsevier, Amsterdam, p 157-166

> Rodríguez P, Arita HT (2004) Beta diversity and latitude of North American mammals: testing the hypothesis of covariation. Ecography 27:547-556

Rosenzweig ML (1995) Species diversity in space and time. University of Cambridge Press, Cambridge

> Salgado CS, Pennings SC (2005) Latitudinal variation in palatability of salt-marsh plants: Are differences constitutive? Ecology 86:1571-1579

- Seliskar DM, Gallagher JL, Burdick DM, Mutz LA (2002) The regulation of ecosystem functions by variation in the dominant plant: a Spartina alterniflora case study. J Ecol 90:1-11

Sodhi NS, Ehrlich PR (2010) Conservation biology for all. Oxford University Press, Oxford

Sommer U, Worm B (2002) Competition and coexistence. Springer-Verlag, Berlin

Soriano A, Sala OE (1984) Ecological strategies in Patagonian arid steppe. Vegetatio 56:9-15

Speziale KL, Ruggiero A, Ezcurra C (2010) Plant species richness-environment relationships across the Subantarctic-Patagonian transition zone. J Biogeogr 37 : 449-464

> Stevens GC (1989) The latitudinal gradient in geographical range: how so many species coexist in the tropics. Am Nat 133:240-256

Stevens RD, Willig MR (2002) Geographical ecology at the community level: perspectives on the diversity of new world bats. Ecology 83:545-560

Tilman D (1982) Resource competition and community structure. Princeton University Press, Princeton

Tscharntke T, Tylianakis JM, Rand TA, Didham RK and others (2012) Landscape moderation of biodiversity patterns and processes - eight hypotheses. Biol Rev Camb Philos Soc 87:661-685

Turner RE (1976) Geographic variation in salt marsh macrophyte production: a review. Contrib Mar Sci 20:47-68

Whittaker RH (1972) Evolution and measurement of species diversity. Taxon 21:213-251 
Whittaker RJ, Willis KJ, Field R (2001) Scale and species richness: towards a general hierarchical theory of species diversity. J Biogeogr 28:453-470

Whittaker RJ, Nogués-Bravo D, Araújo MB (2007) Geographical gradients of species richness: a test of the water-energy conjecture of Hawkins et al. (2003) using European data for five taxa. Glob Ecol Biogeogr 16:76-89 Wiegert RG, Pomeroy LR, Wiebe WJ (1981) Ecology of salt-

Editorial responsibility: Richard Osman,

Edgewater, Maryland, USA marshes: an introduction. In: Pomeroy LR, Wiegert RG (eds) The ecology of a saltmarsh. Springer-Verlag, New York, NY, p 3-20

Willig MR, Kaufman DM, Stevens RD (2003) Latitudinal gradients of biodiversity: pattern, process, scale, and synthesis. Annu Rev Ecol Evol Syst 34:273-309

Zar JH (1999) Biostatistical analysis, 4th edn. Prentice-Hall, Englewood Cliffs, NJ

Submitted: February 18, 2013; Accepted: September 6, 2013 Proofs received from author(s): November 27, 2013 